\title{
Pengaruh Model Pembelajaran Berbasis Masalah Berbantuan Media Komputer terhadap Kemampuan Berpikir Kritis Siswa SMA Negeri 5 Palu
}

\author{
Rudi Santoso, I Wayan Darmadi dan Darsikin \\ rudis9415@yahoo.com \\ Program Studi Pendidikan Fisika FKIP Universitas Tadulako \\ Jl. Soekarno Hatta Km. 9 Kampus Bumi Tadulako Tondo Palu - Sulawesi Tengah
}

\begin{abstract}
Penelitian ini bertujuan untuk mengetahui ada tidaknya pengaruh model pembelajaran berbasis masalah berbantuan media komputer terhadap kemampuan berpikir kritis siswa SMA N 5 Palu. Metode yang digunakan adalah kuasi eksperimen dengan nonequivalent control group design. Populasi penelitian ini adalah seluruh siswa kelas XI IPA SMA N 5 Palu. Pengambilan sampel dilakukan secara purposive sampling dengan sampel penelitian adalah kelas XI IPA I sebagai kelas kontrol dan kelas XI IPA II sebagai kelas eksperimen. Instrumen penelitian berupa tes kemampuan berpikir kritis serta lembar observasi yang telah divalidasi oleh validator dan telah diuji coba lapangan. Peningkatan rata-rata $\mathrm{N}$-gain pada kelas eksperimen adalah 0,57 sedangkan pada kelas kontrol adalah 0,43. Nilai signifikansi hasil uji hipotesis diperoleh lebih kecil dibandingkan dengan nilai a atau $0,026<0,05$, sehingga $\mathrm{H}_{1}$ diterima dan $\mathrm{H}_{0}$ ditolak. Hasil ini menunjukkan bahwa terdapat pengaruh model pembelajaran berbasis masalah berbantuan media komputer terhadap kemampuan berpikir kritis siswa SMA $\mathrm{N}$ 5 Palu.
\end{abstract}

Kata Kunci : Pembelajaran Berbasis Masalah, Kemampuan Berpikir Kritis, Media Komputer

\section{PENDAHULUAN}

Teknologi merupakan hal penting dalam kehidupan saat ini. Penggunaan teknologi yang tepat dalam dunia pendidikan, akan meningkatkan minat belajar siswa. Selain itu, dengan teknologi juga dapat merangsang cara berpikir siswa. Cara berpikir merupakan hal yang sangat penting untuk meningkatkan hasil belajar siswa. Diantara cara bepikir tersebut, berpikir kritis merupakan cara berpikir yang harus dimiliki setiap siswa. Hal ini dikarenakan berpikir kritis merupakan cara berpikir siswa yang menggabungkan semua aspek yang harus ada dan diperlukan dalam pembelajaran, khususnya pelajaran fisika.

Keterampilan berpikir kritis bukan merupakan suatu keterampilan yang dapat berkembang dengan sendirinya seiring dengan perkembangan fisik manusia. Keterampilan ini harus dilatih melalui pemberian stimulus yang menuntut seseorang untuk berpikir kritis. Sekolah sebagai suatu institusi penyelenggara pendidikan memiliki tanggung jawab untuk membantu siswanya mengembangkan keterampilan berpikir kritis [1].

Salah satu alternatif model pembelajaran yang dapat meningkatkan kemampuan berpikir kritis siswa adalah Pembelajaran Berbasis
Masalah (PBM). Pembelajaran berbasis masalah merupakan suatu model pembelajaran dimana siswa mengerjakan permasalahan yang autentik dengan maksud untuk menyusun pengetahuan mereka sendiri, mengembangkan inkuiri dan keterampilan berpikir kritis, mengembangkan kemandirian, dan percaya diri. Pemberian masalah dalam PBM harus memperhatikan dan memahami jenis masalah yang diberikan. Ada dua jenis masalah secara umum yaitu masalah yang tidak terstruktur (illstructure), kontekstual dan menarik (contextual and engaging).

Pemilihan terhadap jenis masalah yang diberikan diharapkan dapat merangsang siswa untuk bertanya dari berbagai perspektif. Melalui PBM siswa juga belajar untuk bertanggung jawab dalam kegiatan belajar, tidak sekedar penerima informasi yang pasif, namun harus aktif mencari informasi yang diperlukan sesuai dengan kemampuan yang dimiliki. Dalam PBM siswa dituntut untuk bertanya dan mengemukakan pendapat, menemukan informasi yang relevan, mencari berbagai cara (alternatif) untuk mendapatkan solusi, dan menemukan cara yang paling efektif untuk menyelesaikan masalah.[2]

Pembelajaran fisika mempelajari permasalahan yang berkaitan dengan fenomena 
alam dan berbagai permasalahan dalam kehidupan sehari-hari. Fenomena alam dapat ditinjau dari objek, persoalan, tema dan tempat kejadiannya. Dalam pembelajaran fisika, siswa setidaknya dapat menguasai empat hal, yaitu ; menguasai konsep-konsep fisika, terampil menggunakan keterampilan berfikir dan keterampilan motorik, memiliki sikap-sikap positif sebagaimana yang dimiliki oleh para fisikawan, mampu menerapkan konsep-konsep fisika dan mempunyai keterampilan berfikir untuk memecahkan masalah sehari-hari. Oleh karenanya, pemilihan model pembelajaran sangat berpengaruh besar dalam proses pembelajaran fisika [3]. Pembelajaran berbasis masalah melibatkan peserta didik dalam proses pembelajaran yang aktif, kolaboratif, berpusat kepada peserta didik, yang mengembangkan kemampuan pemecahan masalah dan kemampuan belajar mandiri yang diperlukan untuk menghadapi tantangan dalam kehidupan dan karier, dalam lingkungan yang bertambah kompleks sekarang ini.[4]

Berdasarkan penelitian yang dilakukan kepada 28 mahasiswa fisika dengan program elektronika pada sub materi termodinamika menunjukkan bahwa terdapat perbedaan yang signifikan dalam inferensi dengan menggunakan pembelajaran berbasis masalah [5]. Penelitian yang lain dilakukan kepada 28 mahasiswa fisika dengan program elektronika pada sub materi termodinamika menunjukkan bahwa, siswa lebih baik setelah dilaksanakan pembelajaran berbasis masalah dibandingkan dengan sebelum pelaksanaan [6].

Penelitian lain yang bersangkutan adalah dilakukan kepada siswa SMA kelas $X$ dengan menggunakan metode penelitian eksperimen kuasi dengan tinjauan gaya kognitif siswa menunjukkan bahwa, rata-rata gain score siswa yang mengikuti model pembelajaran berbasis masalah adalah 0,49 , rata-rata gain score siswa yang mengikuti model pembelajaran konvensional adalah 0,34. Ini berarti siswa yang mengikuti model pembelajaran berbasis masalah memperoleh peningkatan rata-rata skor keterampilan berpikir kritis yang lebih tinggi dibandingkan dengan siswa yang mengikuti model pembelajaran konvensional. [7]

Mengacu pada uraian di atas, dapat terlihat bahwa model pembelajaran berbasis masalah memiliki beberapa keunggulan untuk dapat menggali konsep siswa sehingga dapat meningkatkan kemampuan berpikir kritis siswa. Hal inilah yang melatar belakangi dilakukannya penelitian ini dengan judul "Pengaruh model pembelajaran berbasis masalah berbantuan media komputer terhadap kemampuan berpikir kritis siswa SMA Negeri 5 Palu".

\section{METODE PENELITIAN}

Jenis penelitian yang digunakan adalah jenis penelitian eksperimen kuasi. Adapun desain penelitian yang digunakan adalah nonequivalen control group design. Desain ini hampir sama dengan pretest-posttest control group design pada jenis penelitian true eksperimen design [8] Desain penelitian yang digunakan seperti pada Tabel 1 .

Tabel 1 Nonequivalen Control Group Design

\begin{tabular}{cccc}
\hline Kelompok & Pretest & Perlakuan & Posttest \\
\hline Eksperimen & $\mathrm{O}$ & $\mathrm{X}$ & $\mathrm{O}$ \\
Kontrol & $\mathrm{O}$ & - & $\mathrm{O}$ \\
\hline
\end{tabular}

Populasi pada penelitian ini adalah seluruh siswa kelas XI IPA di SMAN 5 Palu dengan kelas XI IPA I sebagai kelas kontrol yang siswanya mengikuti model konvensional menggunakan model pembelajaran berbasis masalah dan kelas XI IPA II sebagai kelas eksperimen yang siswanya mengikuti model pembelajaran berbasis masalah berbantuan media komputer.

Pengambilan sampel dilakukan menggunakan teknik purposive sampling yaitu teknik pengambilan sampel berdasarkan pertimbangan tertentu.

Instrumen yang digunakan dalam penelitian ini adalah tes untuk melihat kemampuan berpikir kritis siswa pada mata pelajaran fisika yang telah divalidasi oleh validator ahli. Tes tersebut digunakan untuk mengetahui kemampuan berpikir kritis siswa pada mata pelajaran fisika pada kelas yang menjadi sampel penelitian. Analisis data dilakukan dengan menganalisis instrumen terlebih dahulu menggunakan uji validitas item dan reliabilitas tes yang kemudian dengan menganalisis data hasil penelitian menggunakan uji normalitas, uji homogenitas dan uji hipotesis.

\section{HASIL DAN PEMBAHASAN}

Tujuan penelitian ini untuk mengetahui pengaruh model pembelajaran berbasis masalah berbantuan media komputer terhadap kemampuan berpikir kritis siswa SMA Negeri 5 
Palu. Data kemampuan berpikir kritis diperoleh melalui tes. Tes yang digunakan yaitu tes esay dengan jumlah 5 soal. Pada awal penelitian kedua kelas terlebih dahulu diberikan tes awal. Data tes awal digunakan untuk mengetahui bahwa kedua data berasal dari varians yang sama (homogen) atau memiliki kemampuan yang sama. Hasil data pengujian dilakukan menggunakan bantuan SPSS 23. Skor hasil belajar siswa diperoleh dari tes awal dan tes akhir yang dilakukan pada masing-masing kelas yaitu eksperimen dan kontrol. Nilai rata-rata tes awal dan tes akhir dari kedua kelas dapat dilihat pada Tabel 2 .

Tabel 2 Nilai Tes Hasil Belajar Tes Awal dan Tes Akhir

\begin{tabular}{lcccc} 
& Minimum & Maximum & Mean & $\begin{array}{c}\text { Std. } \\
\text { Deviation }\end{array}$ \\
\hline $\begin{array}{l}\text { Hasil Tes } \\
\text { Awal Kelas }\end{array}$ & 6,00 & 11,00 & 8,15 & 1,40 \\
$\begin{array}{l}\text { Eksperimen } \\
\text { Hasil Tes }\end{array}$ & 11,00 & 18,00 & 14,92 & 2,10 \\
$\begin{array}{l}\text { Akhir Kelas } \\
\text { Eksperimen }\end{array}$ & 12,00 & 9,40 & 1,46 \\
$\begin{array}{l}\text { Hasil Tes } \\
\text { Awal Kontrol }\end{array}$ & 7,00 & 17,00 & 13,70 & 1,76 \\
$\begin{array}{l}\text { Hasil Tes } \\
\text { Akhir Kontrol }\end{array}$ & 10,00 & 17,0 \\
\hline
\end{tabular}

Berdasarkan Tabel 2 dapat dilihat bahwa secara kuantitas untuk tes awal dan tes akhir terdapat perbedaan kemampuan berpikir kritis siswa pada materi usaha dan energi antara kelas eksperimen dan kelas kontrol. Hasil pengolahan data ini selanjutnya digunakan untuk menganalisis data melalui uji normalitas, uji homogenitas dan uji hipotesis.

Data yang akan diuji normalitas adalah data hasil Pretest pada kelas eksperimen dan kelas kontrol. Hasil perhitungan analisis uji normalitas Pretest menggunakan uji normalitas Lilliefors (Kolmogorov Smirnov) melalui SPSS 23 dapat dilihat pada Tabel 3.

Tabel 3 Normalitas Distribusi Tes Awal pada Kelas Eksperimen dan Kelas Kontrol

\begin{tabular}{lcccrcl}
\hline & \multicolumn{2}{c}{ Kolmogorov-Smirnov $^{\mathrm{a}}$} & \multicolumn{3}{c}{ Shapiro-Wilk } \\
\cline { 2 - 7 } & Statistic & Df & Sig. & Statistic & Df & Sig. \\
\hline $\begin{array}{l}\text { Kelas } \\
\text { Eksperimen }\end{array}$ & 0,159 & 26 & 0,090 & 0,935 & 26 & 0,103 \\
$\begin{array}{l}\text { Kelas } \\
\text { Kontrol }\end{array}$ & 0,164 & 26 & 0,069 & 0,928 & 26 & 0,070 \\
\hline
\end{tabular}

Kriteria uji normalitas tes yaitu;

Sig $>0,05=$ data berdistribusi normal.

Sig $<0,05=$ data tidak berdistribusi normal
Berdasarkan Tabel 3 diperoleh informasi bahwa kedua uji persyaratan terpenuhi. P-value hasil uji normalitas pada kelas eksperimen nilai signifikan $(0,090)>0,05$ dan kelas kontrol $(0,069)>0,05$, bedasarkan kriteria uji normalitas yang ditetapkan dapat disimpulkan bahwa data hasil pretest berdistribusi normal.

Tabel 4 Normalitas Distribusi Tes Akhir pada Kelas Eksperimen dan Kelas Kontrol

\begin{tabular}{|c|c|c|c|c|c|c|}
\hline & \multicolumn{3}{|c|}{ Kolmogorov-Smirnov ${ }^{a}$} & \multicolumn{3}{|c|}{ Shapiro-Wilk } \\
\hline & Statistic & Df & Sig. & Statistic & Df & Sig. \\
\hline $\begin{array}{l}\text { Kelas } \\
\text { Eksperimen }\end{array}$ & 0,158 & 26 & 0,095 & 0,943 & 26 & 0,154 \\
\hline $\begin{array}{l}\text { Kelas } \\
\text { Kontrol }\end{array}$ & 0,146 & 26 & 0,159 & 0,967 & 26 & 0,545 \\
\hline
\end{tabular}

Kriteria uji normalitas tes yaitu;

Sig $>0,05=$ data berdistribusi normal.

Sig $<0,05=$ data tidak berdistribusi normal

Berdasarkan Tabel 4 diperoleh informasi bahwa kedua uji persyaratan terpenuhi. $P$-value hasil uji normalitas pada kelas eksperimen nilai signifikan $(0,095)>0,05$ dan kelas kontrol $(0,159)>0,05$, bedasarkan kriteria uji normalitas yang ditetapkan dapat disimpulkan bahwa data hasil prosttest berdistribusi normal.

Perolehan uji homogenitas pretest kelas eksperimen dan kelas kontrol pada taraf signifikansi $\alpha=0,05$ diperoleh $p$-value $(0,95)>$ 0,05 , sedangkan untuk posttest diperoleh $p$ value $(0,23)>0,05$. Berdasarkan hasil ini dapat disimpulkan bahwa data hasil pretest dan postest pada kelas eksperimen dan kontrol memiliki varians homogen.

Karena data memenuhi syarat normal dan homogen, maka dilakukan pengujian hipotesis menggunakan uji-t (uji satu pihak). Kriteria penerimaan yakni $\mathrm{H}_{0}$ diterima jika nilai signifikansi yang diperoleh lebih kecil dibandingkan dengan nilai a. Adapun nilai signifikansi yang diperoleh pada penelitian ini adalah $0,03<0,05$, dengan demikian $\mathrm{H}_{1}$ diterima dan $\mathrm{H}_{0}$ ditolak. Artinya bahwa terdapat perbedaan model pembelajaran berbasis masalah berbantuan media komputer dengan pembelajaran konvensional menggunakan model pembelajaran berbasis masalah terhadap kemampuan berpikir kritis siswa.

Adapun nilai rata-rata peningkatan pemahaman konsep yang diperoleh melalui hasil analisa data menggunakan N-Gain untuk kelas eksperimen dan kontrol ditunjukan pada Tabel 5. 
Tabel 5 Hasil Uji Peningkatan Pemahaman Konsep pada Kelas Eksperimen dan Kelas Kontrol

\begin{tabular}{cccc} 
Uraian & Tes awal & Tes akhir & $\begin{array}{c}\text { Rerata } \\
\text { Gain }\end{array}$ \\
\hline Kelas Eksperimen & 8,15 & 14,92 & 0,57 \\
Kelas Kontrol & 9,04 & 13,70 & 0,43 \\
\hline
\end{tabular}

Tabel 5 dapat dilihat peningkatan kemampuan berpikir kritis siswa antara kelas eksperimen dan kelas kontrol. Pada tabel di atas menunjukkan bahwa rata-rata peningkatan kemampuan berpikir kritis siswa pada kelas eksperimen lebih tinggi daripada kelas kontrol. Walaupun dari kriteria n-gain sendiri keduanya termasuk dalam kategori sedang, namun pada kelas eksperimen terdapat beberapa siswa yang memiliki nilai $n$-gain yang tinggi sedangkan pada kelas kontrol tidak ada yang memiliki kriteria tinggi. Hal ini menunjukkan peningkatan kemampuan berpikir kritis siswa pada kelas eksperimen yang menggunakan model pembelajaran berbasis masalah berbantuan media komputer lebih tinggi daripada kelas kontrol yang menggunakan pembelajaran konvensional dengan model pembelajaran berbasis masalah.

Berdasarkan hasil yang diperoleh, terlihat bahwa pada kelas eksperimen kemampuan berpikir kritis siswa mengalami kenaikan yang lebih tinggi daripada kelas kontrol setelah diberi perlakuan berupa proses belajar mengajar menggunakan model pembelajaran berbasis masalah berbantuan media komputer. Kenaikan yang paling signifikan berdasarkan indikator berpikir kritis yang diukur adalah pada saat siswa mengalisis pertanyaan dan bertanya serta menjawab pertanyaan tentang suatu penjelasan atau pernyataan, sedangkan untuk memfokuskan pertanyaan masih kurang. Hal ini berbeda dengan kelas kontrol yang hanya mengalami sedikit kenaikan dari indikator berpikir kritis yang diukur.

Hasil di atas terjadi karena pada kelas eksperimen dilakukan sebuah pengajaran dengan menjadikan siswa sebagai peran utama dalam sebuah proses belajar mengajar, dimana siswa yang akan lebih aktif dalam pembelajaran dan memecahkan masalah yang diberikan dan guru hanya sebagai fasilitator. Ditambah dengan menggunakan media komputer yaitu berupa simulasi menggunakan software makromedia flash lebih membuat proses belajar mengajar dikelas lebih aktif dan menyenangkan sehingga siswa akan lebih mudah memahami materi yang diajarkan. Ketika pembelajaran berlangsung, siswa lebih cenderung mengerjakan masalah yang diberikan oleh guru. Saat siswa diberikan sebuah masalah, siswa berlomba-lomba menjawab masalah yang diberikan, bahkan ada dari beberapa siswa yang memaksakan diri untuk menyelesaikan masalah yang diberikan. Hal ini menunjukkan bahwa siswa lebih bersemangat dan lebih aktif dalam proses belajar mengajar, sehingga proses pembelajaran murni terfokus kepada siswa. Selain itu, dalam proses belajar mengajar yang dilakukan dikelas ini juga menggunakan sistem kerja kelompok dalam menyelesaikan masalah yang diberikan oleh guru dan dirangkai dalam bentuk LKS. Hal ini dilakukan agar terdapat interaksi antar siswa yang nantinya akan membuat siswa akan saling bertukar pendapat dan pikiran untuk mendapatkan solusi terbaik dalam menyelesaikan masalah yang diberikan, kemudian hasil pemikiran dari kelompok tersebut dirangkai menjadi satu dan dipresentasikan didepan kelas. Setelah perwakilan kelompok memaparkan hasil kerja kelompoknya, kelompok lain diberi kesempatan untuk bertanya atau menanggapinya, sehingga terdapat interaksi antar siswa dalam satu kelas. Hal inilah yang membuat siswa lebih cepat menyerap materi pelajaran yang diajarkan. Adapun materi yang diajarkan adalah usaha dan energi. Siswa yang tadinya pasif dalam pembelajaran dengan menerapkan model pembelajaran ini, siswa menjadi bersemangat dan lebih fokus pada pembelajaran.

Hasil Penelitian ini sejalan dengan penelitian yang dilakukan sebelumnya yang berhasil menunjukan bahwa penerapan model pembelajaran bebasis masalah berbantuan simulasi komputer pada materi fluida dinamis dapat meningkatkan penguasaan konsep dan keterampilan berpikir kritis siswa[9]. Penerapan model pembelajaran bebasis masalah berbantuan simulasi komputer pada materi fluida dinamis dapat meningkatkan penguasaan konsep dan keterampilan berpikir kritis siswa[10]. Penelitian yang lainnya juga menunjukkan bahwa ada perbedaan akibat pengaruh model pembelajaran berbasis masalah berbantuan komputer terhadap hasil belajar siswa. Untuk hubungan kemampuan berpikir kritis dan hasil belajar siswa, diperoleh kesimpulan bahwa terdapat hubungan yang positif antara kemampuan berpikir kritis dan 
hasil belajar siswa pada kelas eksperimen maupun kelas kontrol.[11]

Berdasarkan semua data yang telah dijabarkan dapat disimpulkan bahwa, terdapat pengaruh model pembelajaran berbasis masalah berbantuan media komputer terhadap kemampuan berpikir kritis siswa SMA Negeri 5 Palu. Peningkatan kemampuan berpikir kritis tersebut terjadi karena selama proses pembelajaran siswa di tuntut untuk memecahkan masalah yang diberikan dan kemudian menjelaskannya sesuai dengan konsepnya.

Kelebihan dari model pembelajaran ini dibandingkan dengan pembelajaran konvensional adalah keaktifan siswa. Melalui model pembelajaran ini siswa dilibatkan untuk aktif berpikir dan menemukan secara langsung pengertian atau konsep yang ingin diketahuinya. Adapun kekurangan dalam model pembelajaran ini adalah guru harus sabar membimbing siswa agar menemukan sendiri pengertian atau konsep dari materi yang ingin diketahuinya. Selain itu, kekurangan lain dalam menggunakan model pembelajaran ini adalah guru bergantung pada listrik dalam menggunakan medianya, karena menggunakan komputer/laptop dan infokus yang membutuhkan listrik dalam penggunaannya.

\section{KESIMPULAN DAN SARAN}

Berdasarkan hasil penelitian dan analisa data hasil penelitian, diperoleh nilai rata-rata hasil pada tes akhir untuk kelas eksperimen 14,92 dan untuk kelas kontrol 13,70. Nilai signifikan hasil uji hipotesis diperoleh lebih kecil dibandingkan dengan nilai a atau 0,026 $<0,05$, sehingga $\mathrm{H}_{1}$ diterima dan $\mathrm{H}_{0}$ ditolak. Selain itu, hasil ini juga didukung dengan adanya nilai $\mathrm{N}$ Gain yang diperoleh, yaitu untuk kelas eksperimen diperoleh nilai N-Gain sebesar 0,57 dan untuk kelas kontrol diperoleh nilai $\mathrm{n}$-Gain sebesar 0,43. Berdasarkan hasil ini dapat disimpulkan bahwa kemampuan berpikir kritis siswa yang diberi perlakuan model pembelajaran berbasis masalah berbantuan media komputer lebih tinggi dari siswa yang mendapatkan pembelajaran konvensional pada kelas XI SMA Negeri 5 Palu.

Berdasarkan kesimpulan ada beberapa saran yang dapat dikemukakan: (1) Dalam menggunakan model pembelajaran, hal terpenting yang harus diperhatikan adalah karakter siswa. Jika karakter siswa di dalam kelas cenderung senang bermain maka gunakan model pembelajaran yang menyenangkan buat mereka agar siswa lebih bisa memahami serta aktif dalam proses belajar mengajar. (2) Model pembelajaran berbasis masalah dengan berbantuan media komputer dalam pelaksanaannya membutuhkan waktu yang cukup lama serta persiapan yang cukup banyak, sebaiknya peneliti dapat memperhitungkan waktu disetiap fase pembelajaran agar lebih efisien, karena waktu menjadi salah satu kendala dalam proses pembelajaran. (3) Untuk peneliti selanjutnya dapat menerapkan model pembelajaran berbasis masalah berbantuan media komputer dengan materi yang berbeda serta software yang berbeda yang bisa menumbuhkan rasa ke inginan siswa untuk belajar sehingga dapat digunakan sebagai bahan pertimbangan dalam penerapannya disekolah.

\section{DAFTAR PUSTAKA}

[1] Wahyuni, S. (2011). Mengembangkan Keterampilan Berpikir Kritis Siswa Melalui Pembelajaran IPA Berbasis Problem-Based Learning. Tersedia: http://www.pustaka.ut.ac.id/dev25/pdfprosidin g2/fmipa201146.pdf

[2] Husnidar, Ikhsan, M., \& Rizal, S. (2014). Penerapan Model Pembelajaran Berbasis Masalah untuk Meningkatkan Kemampuan Berpikir Kritis dan Disposisi Matematis Siswa. Tersedia: http://www.jurnal.unsyiah.ac.id/DM/article/dow nload/1340/1221

[3] Elok. (2012). Pembelajaran Fisika. [Online]. Tersedia: http://buelok.blogspot.com/2012/04/pembelaja ran-fisika.html

[4] Daruisama, N. (2014). Strategi Pembelajaran Berbasis Masalah. [Online]. Tersedia: http:// www.idsejrah.net/2014/11/strategi-pembelaja ran-berbasismasalah.html

[5] Sulaiman, F., \& Eldy, E.E. (2014). Integrated Pendekatan PBL: Temuan Mahasiswa Fisika terhadap Berpikir Kritis. Tersedia: http://www. ijier.net/assets/integrated-pbl-approach-find ings-towards-physics-students-critical-ijier.net -vol-2-no-2 8.pdf

[6] Sulaiman, F., \& Eldy, E.E. (2013). Pendekatan PBL Terpadu: Temuan Awal Fisika terhadap Berpikir Kritis Mahasiswa dan Berpikir Kreatif-Kritis. Tersedia: $\quad$ http://www.ijhssi.org/papers $\angle \mathrm{v} 2(3) /$ version-4/D2318 25.pdf

[7] Reta, I. K. (2012). Pengaruh Model Pembelajaran Berbasis Masalah terhadap Keterampilan Berpikir Kritis Ditinjau dari Gaya Kognitif Siswa. Tersedia: http://pasca.undiksha.ac. id/ejournal/index.php/jurnal ipa/article/downlo $\mathrm{ad} / 403 / 195$

[8] Sugiyono. (2014). Metode Penelitian Pendidikan. Bandung: Alfabeta. 
[9] Susanti, A., \& Gunawan. (2015). Penerapan Model Pembelajaran Berbasis Masalah Berbantuan Simulasi Komputer Terhadap Penguasaan Konsep dan Keterampilan Berpikir Kritis Siswa pada Materi Fluida Dinamis. Tersedia: http://lppm.ikipmataram.ac.id/wp-content/ uploads/2015/04/Ary-Susanti-PenarapanModel-Pembelajaran-Berbasis-MasalahBerbantuan-Simulasi-Komputer-terhadapPenguasaan-Konsep-Pend-Fisika.pdf

[10] Triyuningsih, E. (2011). Pengaruh Model Pembelajaran Berdasarkan Masalah (Problem Based Learning) Terhadap Kemampuan Berpikir Kritis Siswa. Tersedia: $\underline{\text { http:// }}$ repository.uinjkt.ac.id/dspace/bitstream/12345 6789/1602/1/101621-EKA\%20TRIYUNINGSIH FITK.pdf

[11] Sari, D., \& Tarigan, R. (2014). Pengaruh Model Pembelajaran Berbasis Masalah Berbantuan Komputer Terhadap Hasil Belajar Siswa Pada Materi Pokok Cahay Kelas VIII SMP Negeri 11 Medan. Tersedia: http://jurnal.unimed.ac.id /2012/index.php/inpafi/article/viewFile/1985/1 $\underline{663}$ 